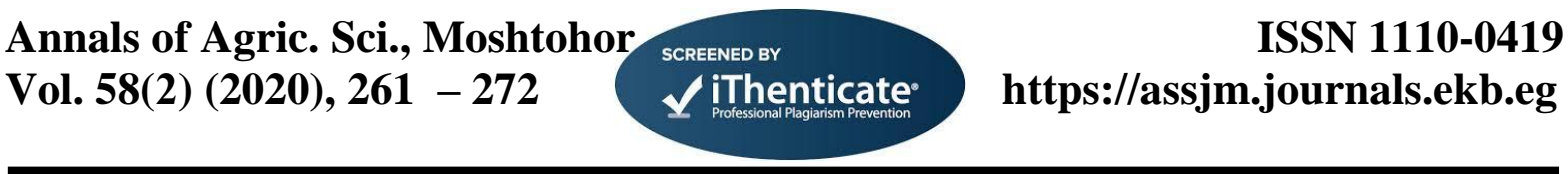

\title{
Effect of Drying Systems on the Parameters and Quality of Dried Basil
}

\author{
Osama M. Abd El-Haq ${ }^{1}$, El-Sayed G. Khater ${ }^{2}$ Adel H. Bahnasawy ${ }^{3}$ and \\ Hossam M. T. El-Ghobashy ${ }^{3}$ \\ ${ }^{1}$ Graduate Student of Agric. Eng. Dep., Fac. of Agric., Benha Univ., Egypt \\ ${ }^{2}$ Associate Professor of Agric. Eng., Fac. of Agric., Benha Univ., Egypt \\ ${ }^{3}$ Professor of Agric. Eng., Fac. of Agric., Benha Univ., Egypt \\ ${ }^{3}$ Researcher, Agric. Eng. Res. Inst., Agric. Res. Center, Egypt \\ Corresponding author: alsayed.khater@fagr.bu.edu.eg
}

\begin{abstract}
The main aim of this study is to investigate the possibility of drying the basil plants under different conditions. Fresh basil was dried using different systems: sun-drying, shadow-drying, room-drying, solar-drying and oven-drying systems. Weight losses, moisture content and oil content were recorded. Drying parameters were studied to determine the equilibrium moisture contents (EMC) using different models. The obtained results indicated that the accumulated weight loss of basil plants increased from 3.57 to $83.76,2.12$ to $70.48,0.72$ to $82.07,0.44$ to 84.34 and 1.29 to $84.90 \%$, for sun-drying system, shadow-drying system, room-drying system, solar-drying system and oven-drying system, respectively. The moisture content of basil plants decreased from 515.95 to $6.91,490.18$ to $6.59,479.97$ to $4.66,538.02$ to 0.93 and 565.40 to $5.40 \%$ d.b. for sun-drying system, shadow-drying system, room-drying system, solar-drying system and oven-drying system, respectively. The highest value of equilibrium moisture contents were 13.25 and $35.16 \%$ at 10 and $90 \%$ equilibrium relative humidity was found from Modified Chung-Pfost equation under room system. The lowest value of equilibrium moisture contents were 0.91 and $16.58 \%$ at 10 and $90 \%$ equilibrium relative humidity was found for modified Oswin equation for oven system. The basil oil content values were 2.3, 2.5, 2.9, 2.7 and $2.0 \%$ for the sun-drying, shadow-drying, room-drying, solar-drying and oven-drying, respectively.
\end{abstract}

Keywords: Basil - Sun-drying - Solar-drying - Oven-drying - Equilibrium Moisture Content - Oil content

\section{Introduction}

Herbal plants cultivated in all over the world particularly in Egypt for both local consumption and export. The sweet basil is one of the most important aromatic plants in Egypt. Its cultivated area is about 5050.6 feddans, producing about 9031.82 ton/year from green plants and 135.46 ton essential oil (GAEO, 2017).

Drying is the most common and effective method that increases the shelf life of herbs which inhibit the microorganisms growth and preventing some biochemical reactions that may alter the organoleptic and nutritional characteristics of the dried leaf. However, drying must be performed carefully in order to preserve the aroma, appearance and nutritional characteristics of the raw herbs (Crivelli et al., 2002). The drying may cause losses in volatilities or formation of new volatilities as a result of oxidation reactions, esterification reactions (Diaz-Maroto et al., 2002).

Sweet basil is a popular culinary herb and its essential oil has been used for many years to flavour foods, as an ingredient of dental and oral health care products and in fragrances (Lachowicz et al., 1998). Basil (Ocimum basilicum L.) belongs to the family Lamiaceae is an annual, herbaceous, white to purple flowering plant, 20-60 cm tall, that originated in Iran and India (Özcan et al., 2005 and Chalchat and Özcan, 2008) and has become a major essential oil cultured commercially in some countries. The areil parts, especially leaves of sweet basil are widely used to enhance the flavor of foods such as salads, pasta, tomato products, vegetables, pizza, meat, soups, marine foods, confectioneries and often products (Özcan and Chalchat, 2002 and Ghasemi Pirbalouti et al., 2013a).

The relation between Equilibrium Relative Humidity (ERH) and Equilibrium Moisture Content (EMC) is called moisture sorption isotherm (MSI) (Soysal and Oztekin 1999). This information is required for drying and storage of agricultural and food products, for instance to maintain the quality in the storage period. This knowledge is also required to stop the drying process at the aimed moisture content to avoid quality losses and to save energy (Hamer $\boldsymbol{e t}$ al. 2000).

EMC is the moisture content of a hygroscopic material reaching the balance with a particular environment in terms of temperature and relative humidity. EMC of the product is the final result of moisture exchange between the product and the air surrounding the sample. In this condition, the water in a product is in balance with the moisture in the surrounding atmosphere (Silakul and Jindal 2002). The relative humidity in this condition is known as the Equilibrium Relative Humidity (ERH) (Soysal and Oztekin 1999). Moisture sorption isotherms are either measured during desorption (starting from the wet 
state) or during adsorption (starting from the dry state).

The herbal and medicinal plants are perishable. Keeping their quality and prolonging the shelf life is required by drying them, therefore, the main aim of this work is to study the drying parameters and basil quality under different drying systems.

\section{Materials and methods:}

The experiment was carried out at Agricultural and Bio-Systems Engineering Department, Faculty of Agriculture Moshtohor, Benha University, Egypt (latitude $30^{\circ} 21^{\prime} \mathrm{N}$ and $31^{\circ} 13^{`} \mathrm{E}$ ). During the period of June and July, 2019 season.

1.1. Materials:

The fresh basil was brought from the Faculty of Agriculture Farm, Moshtohor, Benha University after harvesting for primary analysis.

\subsubsection{Drying systems:} as follows:-

The basil was dried using different systems

\section{1- Sun-drying:}

Basil leaves were folded into a thin sheet of paper and placed on a flat plate in direct sunlight. Tray with a dimension of $(0.8 \mathrm{~m}$ long, $0.6 \mathrm{~m}$ wide and 0.1 m high).

\section{2- Shadow-drying:}

Basil leaves were folded into a thin sheet of paper and placed on a flat plate $(0.8 \mathrm{~m}$ long, $0.6 \mathrm{~m}$ wide and $0.1 \mathrm{~m}$ high) in shadow.

\section{3- Room temperature-drying:}

Basil leaves were folded into a thin sheet of paper and placed on a flat plate $(0.8 \mathrm{~m}$ long, $0.6 \mathrm{~m}$ wide and $0.1 \mathrm{~m} \mathrm{high)} \mathrm{in} \mathrm{room} \mathrm{was} \mathrm{air-drying} \mathrm{at}$ ambient temperature.

\section{4- Hybrid-solar drying:}

Fig. 1 illustrates the hybrid-solar drying system description. It shows the system which consists of solar collector, drying chamber, trays, blower and burner.

The solar collector consists of three major components, namely: The glass cover has dimensions of $4.0 \mathrm{~m}$ long, $1.0 \mathrm{~m}$ width and $5.5 \mathrm{~mm}$ thickness. The cover is fixed on a wooden frame with a thickness of $10 \mathrm{~cm}$. It is divided into two lanes, $50 \mathrm{~cm}$ wide each. The absorber plate is made from corrugated black aluminum plate. The insulation is a thermal wool with a $5.0 \mathrm{~cm}$ thickness.

The drying chamber has a length of $1.0 \mathrm{~m}$, width of $0.75 \mathrm{~m}$ and height of $1.0 \mathrm{~m}$. It is made of galvanized steel (5 mm thickness). The inner surface of drying chamber is covered an insulated materials to reduce heat loss from the walls.

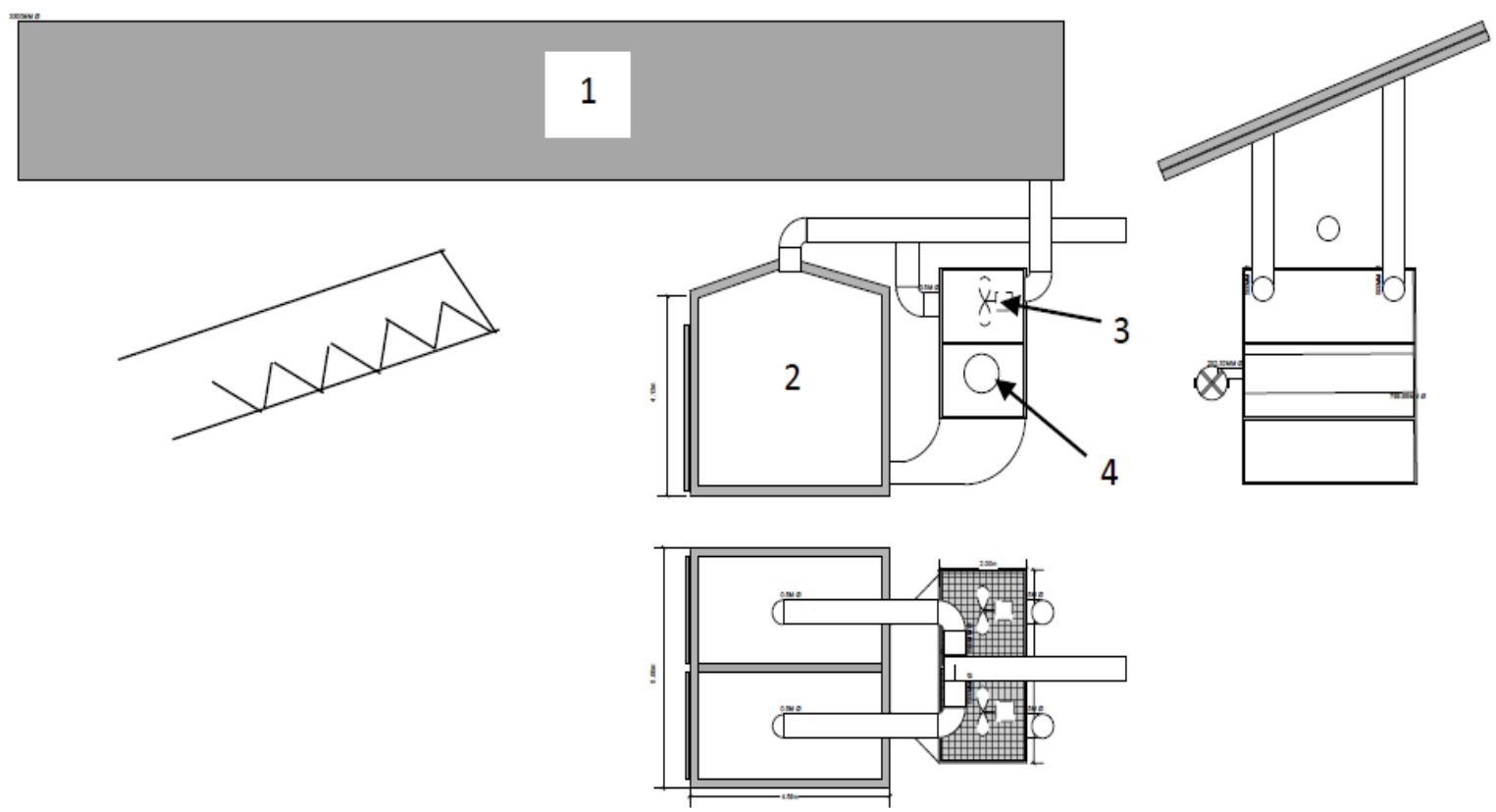

Fig. 1. Elevation, plan and side view for the hybrid-solar dryer.

1: solar collector

3: blower

The trays are made of stainless steel and have a length of $0.90 \mathrm{~m}$, width of $0.65 \mathrm{~m}$ and height of 0.25 $\mathrm{m}$. They have perforated bottom which allows heated air to pass through products.

Two air blowers were used to force and recirculate the drying air to the drying chamber (Model C.C.P. Parma - Flow Rate $6.6 \mathrm{~m}^{3} \mathrm{~h}^{-1}-\mathrm{RPM} 2800-$ Power $150 \mathrm{~W}, 220 \mathrm{~V} 50 \mathrm{~Hz}$, Italy).

$$
\text { 2: drying chamber }
$$

4: burner
The dryer uses a chamber burner system in which heat is being produced. The burner incorporates switches with a sparking mechanism that ignites the gas when it is fed from the gas bottle.

\section{Oven-drying:}

Basil plants were spread evenly on baking sheets and placed in conventional laboratory oven (Fisher 
Scientific Isotemp Oven, Model 655F Cat. No. 13245-655, Fisher Scientific, Toronto, Ontario, Canada).

1.2. Methods:
Basil was cleaned by removing undesired stems and waste materials as shown in the process flow chart (fig. 2).

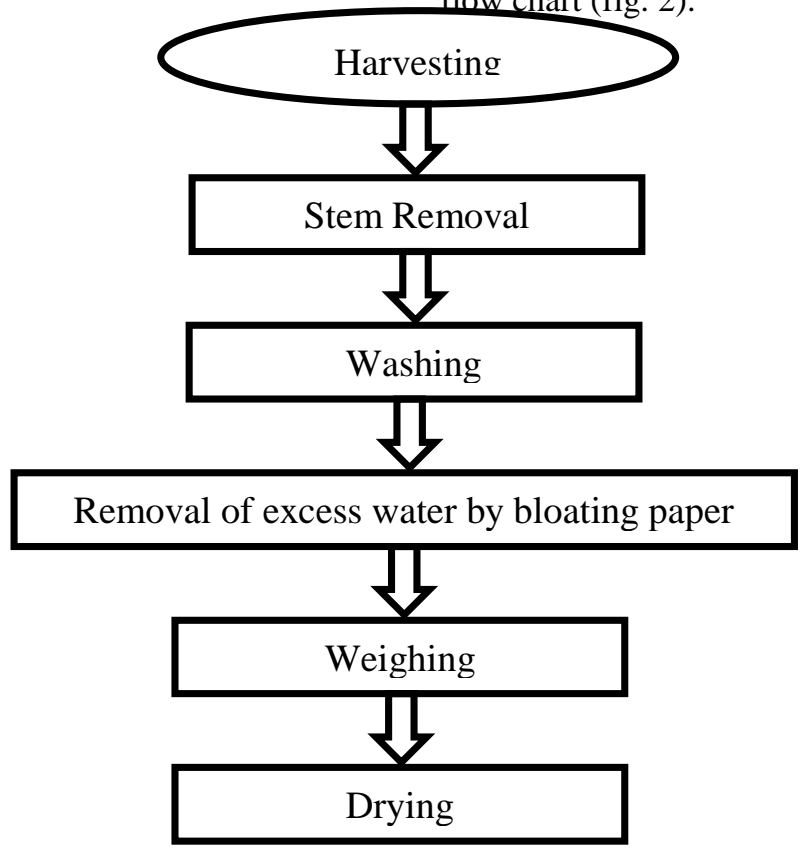

Fig. 2. Flow chart of basil processing

\subsubsection{Drying systems:}

Five different drying systems were used to dry basil. The basil was dried using one of the following methods. The reported data are means of three replications.

\section{1- Sun-drying:}

Two kilograms $(2 \mathrm{~kg})$ basil leaves were folded into a thin sheet of paper and placed on a flat plate in direct sunlight at an average temperature of $35.5 \pm 3.7^{\circ} \mathrm{C}$ and relative humidity of $57.5 \pm 2.0 \%$.

\section{2- Shadow-drying:}

Two kilograms $(2 \mathrm{~kg})$ basil leaves were folded into a thin sheet of paper and placed on a flat plate in shadow at an average temperature of $35.2 \pm 2.0^{\circ} \mathrm{C}$ and relative humidity of $68.5 \pm 3.0 \%$.

\section{3- Room temperature-drying:}

Two kilograms $(2 \mathrm{~kg})$ basil leaves were folded into a thin sheet of paper and placed on a flat plate in room was air-drying at ambient temperature at an average temperature of $32.0 \pm 2.0^{\circ} \mathrm{C}$ and relative humidity of $58.0 \pm 4.0 \%$.

\section{4- Solar-drying:}

Basil leaves were folded into a thin sheet of paper and placed on a flat plate in solar dryer at an average temperature of $51.0 \pm 9.0^{\circ} \mathrm{C}$ and relative humidity of $40.0 \pm 13.0 \%$.

\section{5- Oven-drying:}

Two kilograms (2kg) basil leaves were spread evenly on baking sheets and placed in conventional laboratory oven at temperature of $65^{\circ} \mathrm{C}$.

\subsubsection{Measurements:}

The mass was measured by electric digital balance (Model HG - 5000 - Range 0 - $5000 \mathrm{~g} \pm 0.01 \mathrm{~g}$, Japan) hourly for sun, shadow and ambient air drying methods and every 15 minutes for solar and oven drying methods. Temperature and relative humidity were recorded by using a HOBO Data Logger (Model HOBO U12 Temp/RH/Light - Range -20 to $70^{\circ} \mathrm{C}$ and 5 to $95 \%$ RH, USA) every hour. The content of oil was determined in basil plants according to (Kiferle $\boldsymbol{e t}$ al., 2011).

\subsubsection{Calculations:}

\section{- Moisture content:}

Moisture content of the fresh and dried basil leaves was determined using conventional laboratory oven kept at $105{ }^{\circ} \mathrm{C}$ until constant weight was reached. Triplicate determinations were made and the moisture content calculated as the following equation:

$$
M C=\frac{\mathrm{M}_{\text {wet }}-M_{d r y}}{\mathrm{M}_{\mathrm{dry}}} \times 100
$$

Where:

$\mathrm{MC}$ is the moisture content, $\%$ d.b.

$\mathrm{M}_{\text {wet }}$ is the wet mass of samples, $\mathrm{g}$

$\mathrm{M}_{\text {dry }}$ is the dry mass of samples, $\mathrm{g}$

- Equilibrium moisture content:

A number of equations have been suggested in literature to describe the relationship between equilibrium moisture content (EMC) and equilibrium relative humidity (ERH). The modified Henderson, modified Oswin and modified Halsey, modified Chung-Pfost and GAB equation (Chen, 2002) have been adopted by the American Society of Agricultural Engineers as standard equations for describing sorption isotherms (ASAE, 2003). We transformed the equations to get EMC as dependent variable and $\mathrm{ERH}$ as independent variable.

Modified Henderson 
$E M C=\left(-\frac{1}{C_{1}\left(T+C_{2}\right)} \ln (1-E R H)\right)^{1 / C_{3}}$

Modified Halsey

$E M C=\left(\frac{-\exp \left(C_{1}+C_{2} T\right)}{\ln (E R H)}\right)^{1 / C_{3}}$

Modified Oswin

$E M C=\left(C_{1}+C_{2} T\right)\left(\frac{E R H}{1-E R H}\right)^{1 / \mathrm{C}_{3}}$

Modified Chung-Pfost

$E M C=\frac{1}{C_{1}} \ln \left(\ln (E R H) \frac{\left(C_{2}-T\right)}{C_{3}}\right)$

GAB equation

$E M C=\frac{C_{1} C_{2} C_{3}(E R H)}{\left[1-C_{2}(E R H)\right]\left[1-C_{2}(E R H)+C_{2} C_{3}(E R H)\right]}$
Where:

ERH is the equilibrium relatize humidity, $\%$

$\mathrm{T}$ is the temperature, ${ }^{\circ} \mathrm{C}$

$\mathrm{C}_{1}, \mathrm{C}_{2}$ and $\mathrm{C}_{3}$ are the constants

The parameters $\mathrm{C}_{2}$ and $\mathrm{C}_{3}$ in the $\mathrm{GAB}$ equation are correlated with temperature using the following equations (Lahsasni et al., 2004):

$C_{2}=C_{4} \exp \left(\frac{C_{6}}{R T_{a}}\right)$

$C_{3}=C_{5} \exp \left(\frac{C_{7}}{R T_{a}}\right)$

Where:

$\mathrm{C}_{4}, \mathrm{C}_{5}, \mathrm{C}_{6}$ and $\mathrm{C}_{7}$ are coefficients

$\mathrm{T}_{\mathrm{a}}$ is the absolute ter( $\left.\bar{\phi}\right)$ rature, $\mathrm{K}$

$\mathrm{kJ} / \mathrm{kmol} \mathrm{K}$

$\mathrm{R}$ is the universal gas constant, $\mathrm{R}=8.314$

Table (1) shows the coefficients for Henderson, Halsey, Oswin, Chung-Pfost and GAB equations of assil leaves for different drying sy(a)ms.

Table 1. The coefficients for Henderson, Halsey, Oswin, Chung-Pfost and GAB equations of basil leaves for different drying systems (Arabhosseini et al., 2005).

\begin{tabular}{cccccc}
\hline \multirow{2}{*}{ Coefficient } & \multicolumn{5}{c}{ Equation } \\
\cline { 2 - 5 } & Henderson & Halsey & Oswin & $\begin{array}{c}\text { Chung- } \\
\text { Pfost }\end{array}$ & Gab \\
\hline $\mathrm{C}_{1}$ & 0.1151 & -3.235 & 0.156 & 13.37 & 0.049 \\
$\mathrm{C}_{2}$ & 65.15 & $-9.62 \times 10^{-3}$ & $-8.20 \times 10^{-4}$ & 13.27 & \\
$\mathrm{C}_{3}$ & 1.387 & 1.499 & 2.053 & 234.27 & 0.652 \\
$\mathrm{C}_{4}$ & & & & $1.74 \times 10^{-3}$ \\
$\mathrm{C}_{5}$ & & & & 997.96 \\
$\mathrm{C}_{6}$ & & & & 25000 \\
$\mathrm{C}_{7}$ & & & & \\
\hline
\end{tabular}

\section{Results and Discussion:}

\section{Weight loss:}

Fig. (3) shows the accumulated weight loss of basil plants that dried under different drying systems (sundrying, shadow-drying, room temperature-drying, solar-drying and oven-drying) at different drying air temperature during experimental period. The results indicate that the accumulated weight loss of basil plants increases with increasing drying period. It could be seen that the accumulated weight loss of basil plants increased from 3.57 to $83.76 \%$, when the drying period increased from 1 to 40 hours at drying air temperature ranged from 34.2 to $44.5^{\circ} \mathrm{C}$ for sundrying system. 


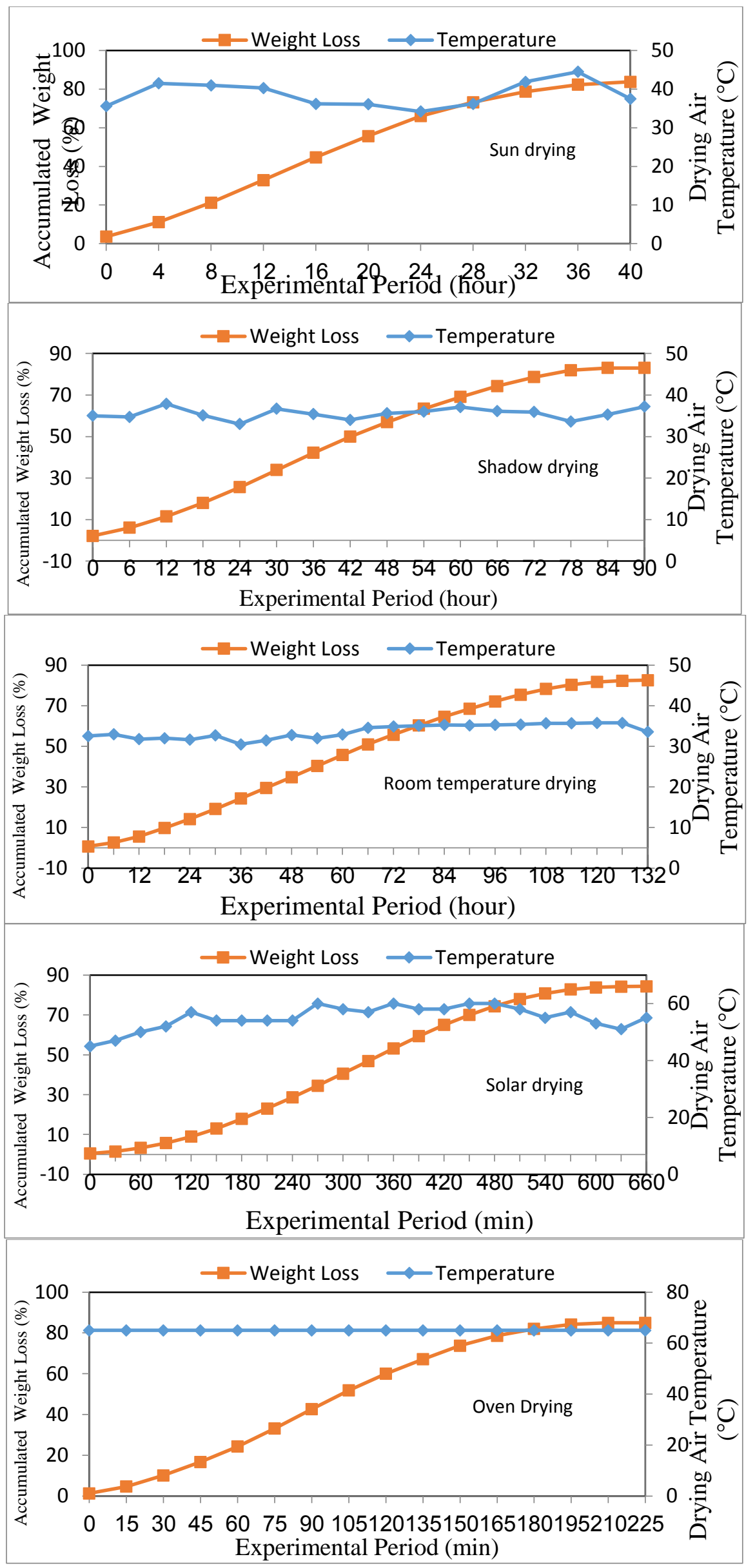


Fig. (3): The accumulated weight loss of basil plants at different drying systems during experimental period.

For shadow-drying system, the accumulated weight loss of basil plants increased from 2.12 to $70.48 \%$, when the drying period increased from 1 to 102 hours at drying air temperature ranged from 33.0 to $37.9^{\circ} \mathrm{C}$. For room temperature-drying system, the accumulated weight loss of basil plants increased from 0.72 to $80.07 \%$, when the drying period increased from 1 to 132 hours at drying air temperature ranged from 30.5 to $35.8^{\circ} \mathrm{C}$. For solar-drying system, the accumulated weight loss of basil plants was increased from 0.44 to $84.34 \%$, when the drying period increased from 1 to $660 \mathrm{~min}$ at drying air temperature ranged from 45.00 to $60.00^{\circ} \mathrm{C}$. For oven-drying system, the accumulated weight loss of basil plants was increased from 1.29 to $84.90 \%$, when the drying period increased from 1 to $225 \mathrm{~min}$ at drying air temperature was $65^{\circ} \mathrm{C}$.

The results also indicate that the shorter drying period (225 min) was occurred under the oven-drying system due to the higher temperature $\left(65^{\circ} \mathrm{C}\right)$ and lower relative humidity (10\%). Meanwhile, the longer drying period (132 hours) was occurred under the room temperature-drying system due to the lower temperature $\left(30.5\right.$ to $35.8^{\circ} \mathrm{C}$ ) and higher relative humidity ( 51.92 to $61.44 \%$ ). The trend of these results agreed with those obtained by Khater and Bahnasawy (2017).

\subsection{Moisture content:}

Fig. (4) shows the moisture content of basil plants under different drying systems (sun-drying, shadowdrying, room temperature-drying, solar-drying and oven-drying) during experimental period. The results indicate that the moisture content of basil plants decreases with increasing drying period for all drying systems. It could be seen that the moisture content of basil plants decreased from 515.95 to 6.91 (by $98.66 \%) \%$ d.b., when the drying period increased from 1 to 40 hours for sun-drying system. For shadowdrying system, the moisture content of basil plants decreased from 490.97 to 6.59 (by $98.66 \%$ ) \% d.b., when the drying period increased from 1 to 102 hours. For room temperature-drying system, the moisture content of basil plants decreased from 479.97 to 6.66 (by $98.61 \%$ ) \%, when the drying period increased from 1 to 132 hours. For solar-drying system, the moisture content of basil plants decreased from 538.02 to 0.93 (by $99.83 \%$ ) \% d.b., when the drying period increased from 1 to $660 \mathrm{~min}$. For oven-drying system, the moisture content of basil plants decreased from 565.40 to 5.40 (by 99.04\%) \% d.b., when the drying period increased from 1 to $225 \mathrm{~min}$. These results were in agreement with those obtained by Özcan et al. (2005), Arafa (2007) and Khater et al. (2019).

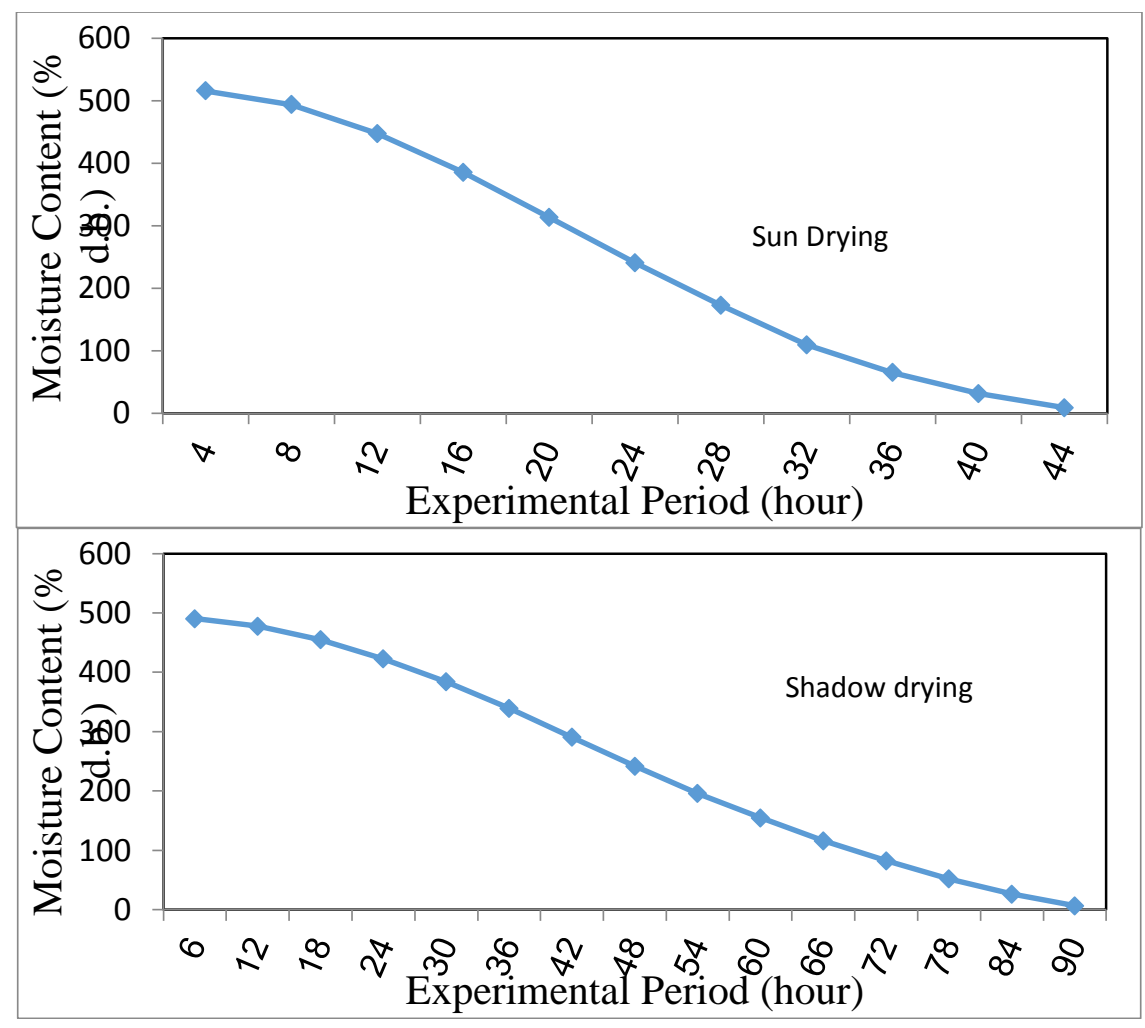



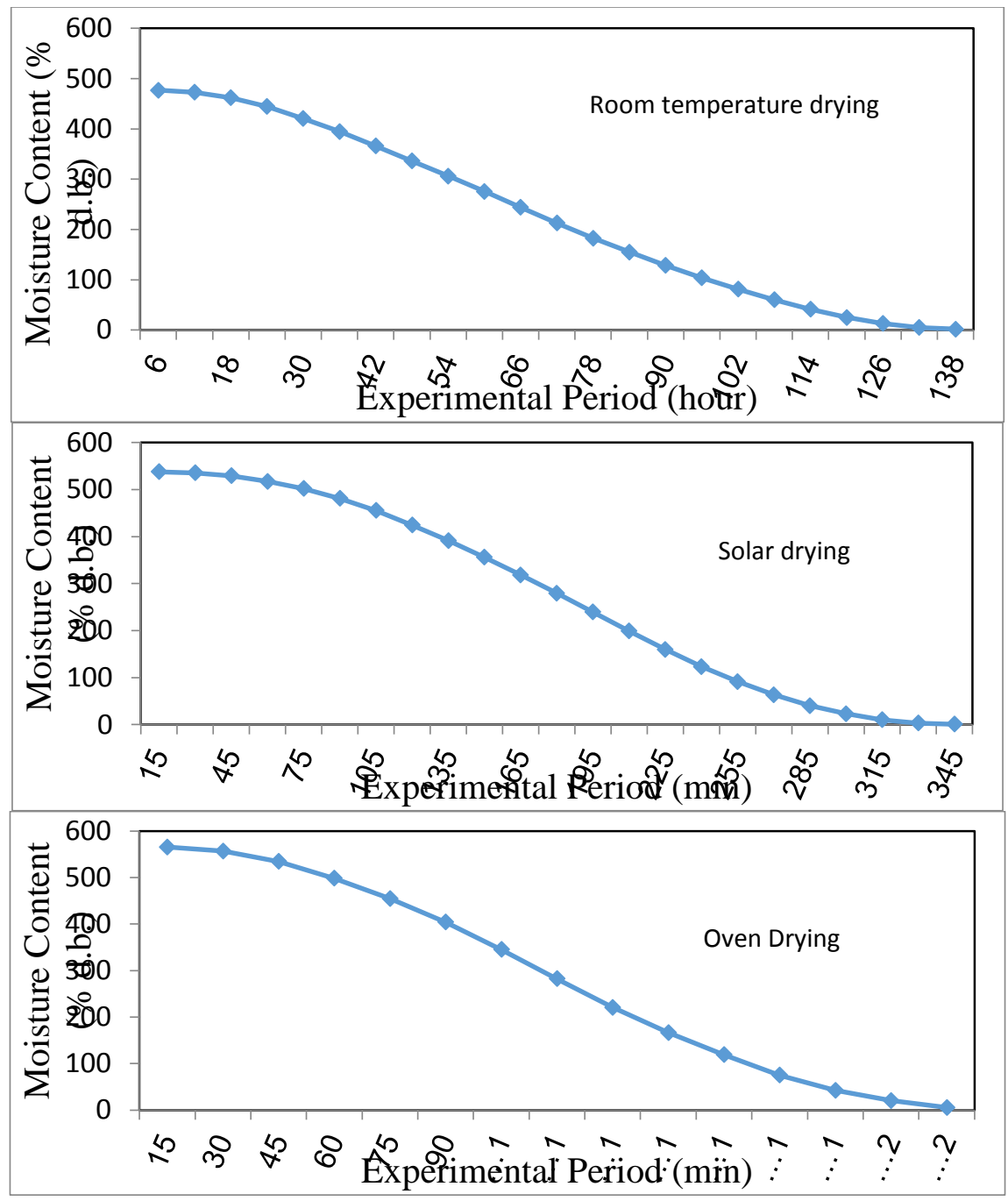

Fig. (4): The moisture content of basil plants for different drying systems.

The results indicate that the highest rate of the decrease moisture content of baisl plants (99.83\%) was happened under the solar-drying system. Meanwhile, the lowest rate of the decrease moisture content of baisl plants (98.61\%) was found at room system. The trend of these results agreed with those obtained by Danso-Boateng (2013).

\subsection{Equilibrium moisture content:}

Fig. (5) shows the equilibrium moisture content of basil plants for different drying systems (sun-drying, shadow-drying, room temperature-drying, solardrying and oven-drying) and different equation models (modified Henderson, modified Halsey, modified Oswin, modified Chung-Pfost and Gab models).

The results indicate that the equilibrium moisture content of basil plants increases with increasing equilibrium relative humidity for different drying systems. It could be seen that the equilibrium moisture content of basil plants was increased from 3.06 to $28.28,3.12$ to $28.84,3.19$ to $29.45,2.79$ to 25.85 and 2.52 to $23.33 \%$ for sun, shadow, room temperature, solar and oven drying systems, respectively, when the equilibrium relative humidity increased from 10 to 90
$\%$ for modified Henderson equation. For modified Halsey equation, the EMC of basil plants was increased from 5.84 to $45.71,5.94$ to $46.49,6.05$ to $47.34,5.37$ to 41.99 and 4.80 to $37.58 \%$ for sun, shadow, room temperature, solar and oven drying systems, respectively, when the equilibrium relative humidity increased from 10 to $90 \%$. For modified Oswin equation, the EMC of basil plants was increased from 1.43 to $16.85,1.98$ to $16.88,2.73$ to $16.90,1.14$ to 16.73 and 0.91 to $16.58 \%$ for sun, shadow, room temperature, solar and oven drying systems, respectively, when the ERH increased from 10 to $90 \%$. For modified Chung-Pfost equation, the EMC of basil plants was increased from 11.13 to $33.05,12.09$ to $34.00,13.25$ to $35.16,7.70$ to 29.62 and $26.72 \%$ for sun, shadow, room temperature, solar and oven drying systems, respectively, when the ERH increased from 10 to $90 \%$. For GAB equation, the EMC of basil plants was increased from 3.90 to 34.46 , 3.99 to $35.26,3.68$ to $36.16,3.47$ to 31.11 and 2.87 to $27.83 \%$ for sun, shadow, room temperature, solar and oven drying systems, respectively, when the ERH increased from 10 to $90 \%$. 


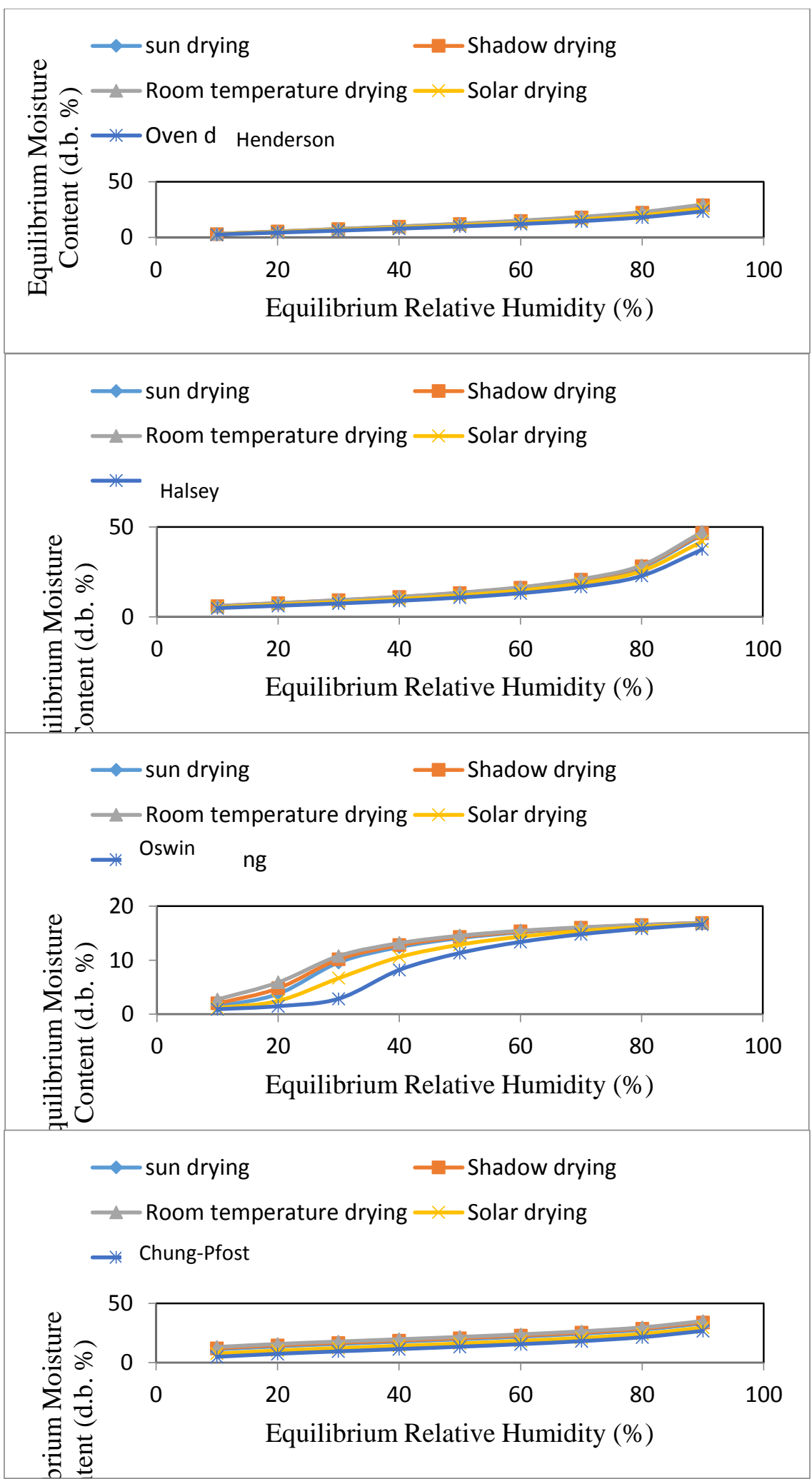




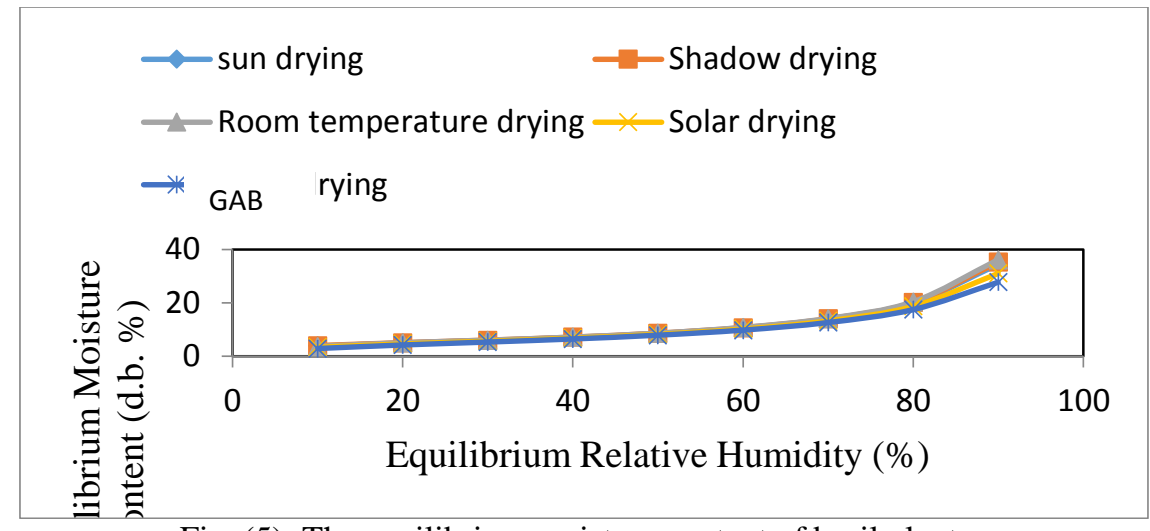

Fig. (5): The equilibrium moisture content of basil plants.

The results indicated that the highest value of equilibrium moisture content was found from Modified Chung-Pfost equation under room system. It could be seen that the equilibrium moisture contents were 13.25 and $35.16 \%$ at 10 and $90 \%$ equilibrium relative humidity for room temperature system. Meanwhile, the lowest value of equilibrium moisture content was found for modified Oswin equation for oven system. It could be seen that the equilibrium moisture contents were 0.91 and $16.58 \%$ at 10 and 90 $\%$ equilibrium relative humidity for oven system.

\subsection{Content of oil:}

Fig. (6) shows the basil oil content for different drying systems (sun-drying, shadow-drying, room temperature-drying, solar-drying and oven-drying) at the end of experiment. It could be seen that the basil oil content values were 2.3, 2.5, 2.9, 2.7 and $2.0 \%$ for the sun-drying, shadow-drying, room temperaturedrying, solar-drying and oven-drying, respectively. The results indicate that the highest value of the basil oil content $(2.9 \%)$ was obtained when the basil dried at room temperature system. Meanwhile, the lowest value of the basil oil content $(2.0 \%)$ was found at the oven-drying system.

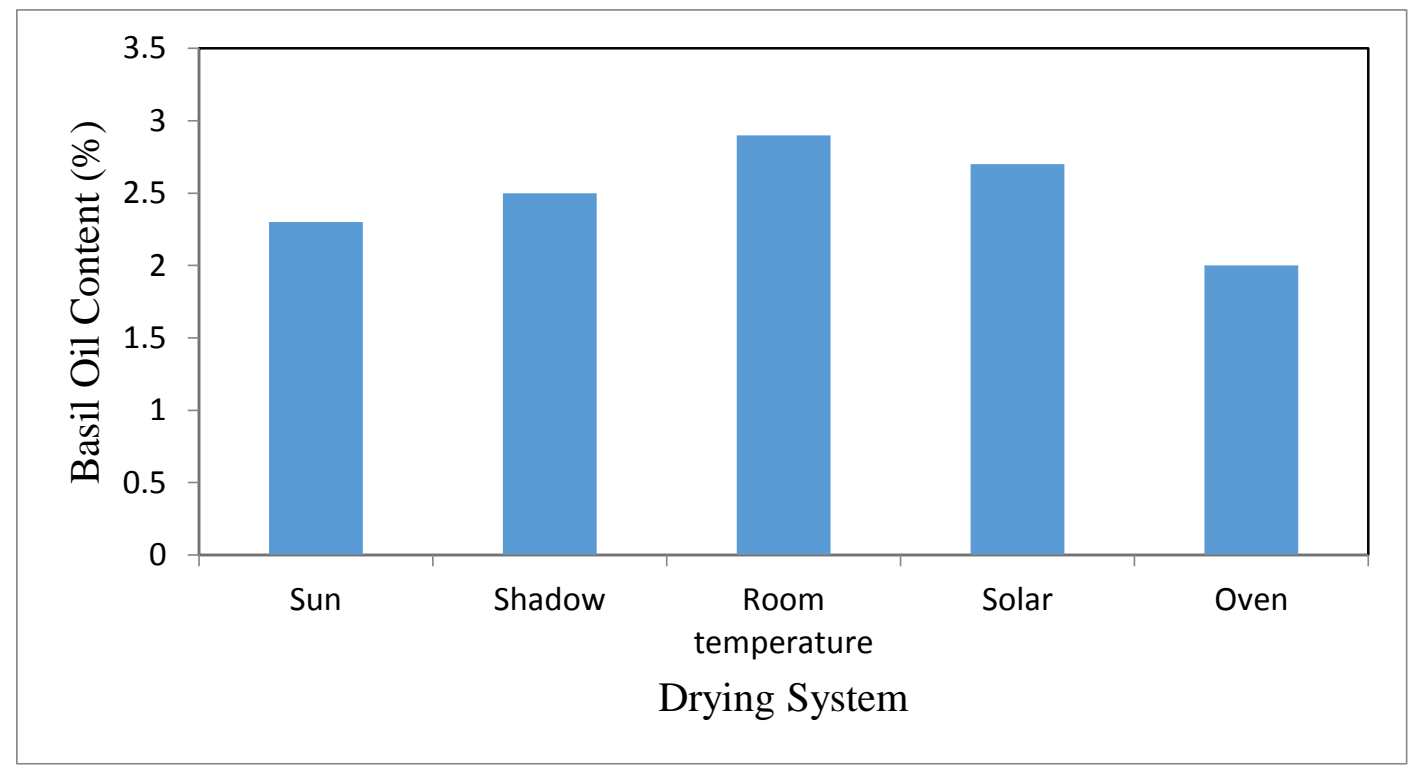

\section{Conclusion:}

The experiment was carried out to study was conducted to investigate the possibility of drying the basil plants under different conditions. The obtained results can be summarized as follows:

- The accumulated weight loss of basil plants increased from 3.57 to $83.76,2.12$ to 70.48 , 0.72 to $82.07,0.44$ to 84.34 and 1.29 to 84.90 $\%$, for sun-drying system, shadow-drying system, room temperature-drying system, drying systems.

solar-drying system and oven-drying system, respectively.

- The moisture content of basil plants decreased from 515.95 to $6.91,490.18$ to $6.59,479.97$ to $4.66,538.02$ to 0.93 and 565.40 to $5.40 \%$ d.b. for sun-drying system, shadow-drying system, room temperaturedrying system, solar-drying system and oven-drying system, respectively.

- The highest value of equilibrium moisture contents were 13.25 and $35.16 \%$ at 10 and 
$90 \%$ equilibrium relative humidity was found from Modified Chung-Pfost equation under room temperature system.

- The lowest value of equilibrium moisture contents were 0.91 and $16.58 \%$ at 10 and 90 $\%$ equilibrium relative humidity was found for modified Oswin equation for oven system.

- $\quad$ The basil oil content values were 2.3, 2.5, $2.9,2.7$ and $2.0 \%$ for the sun-drying, shadow-drying, room temperature-drying, solar-drying and oven-drying, respectively.

\section{References:}

Arabhosseini, A., Huisman W., van Boxtel A. and Müller J. (2005). Modeling of the Equilibrium Moisture Content (EMC) of Tarragon (Artemisia Dracunculus L.). International Journal of Food Engineering, 1 (5): 1 - 15 .

Arafa, G. K. (2007). Optimum drying conditions for thin-layer drying of sweet basil. Misr J. Ag. Eng., 24(3): $540-556$.

ASAE (2003). Moisture relations of plant-based agricultural products. ASAE Standards 2003; Standards Engineering Practics Data (50th Edition) D245.5: 538.

Chalchat, J. C and Özcan M.M. (2008). Comparative essential oil composition of flowers, leaves and stems of basil (Ocimum basilicum L.) used as herb. Food Chem., 110: $501-503$.

Chen, C. (2002). Sorption isotherms of sweet potato slices. Biosystems Engineering 83(1): 85 - 95.

Crivelli, G., Nani R.C. and Di Cesare L.F. (2002). Influence of processing on the quality of dried herbs. Atti VI Giornatescientifiche SOI. Spoleto, 2: 463 - 464.

Danso-Boateng E. (2013). Effect of drying methods on nutrient quality of Basil (Ocimum viride) leaves cultivated in Ghana. International Food Research Journal, 20(4): 1569-1573.

Diaz-Maroto, M.C., Pérez-Coello M.S. and Cabezudo M.D. (2002). Effect of drying method on the volatilities in bay leaf (Laurusnobilis L.). Journal of Agricultural Food Chemistry, 50: 4520 - 4524.

GAEO (General of Agricultural Economics organization) - Ministry of Agriculture and Land Reclamation (2017). Acreage statistics and vegetable production in the Arab Republic of Egypt (unpublished).

Ghasemi Pirbalouti, A., Mahdad E. and Craker L. (2013a). Effects of drying methods on qualitative and quantitative properties of essential oil of two basil landraces. Food Chem., 141: $2440-2449$.
Hamer, P.J.C., Knight A.C., McGechan M.B. and Cooper G. (2000). Model for predicting the field drying characteristics of grass conditioned by maceration (severe treatment). Journal of Agricultural Engineering Research, 75(3): 275289.

Henderson, S.M. and Pabis, S. (1961). Grain drying theory: Temperature effect on drying coefficient. Agric. Eng. Res., 10:169 - 174.

Khater, E.G., Bahnasawy A.H. (2017). Basil Drying Performance and Quality under Different Drying Systems. $2^{\text {nd }}$ International Sino-Egyptian Congress on Agriculture, Veterinary Sciences and Engineering ( $2^{\text {nd }}$ ISEC-AVE), $7-10$ October, 2017, Egypt.

Khater, E.G., Bahnasawy A.H., Hamouda R.M. (2019). Dehydration of chamomile flowers under different drying conditions. Journal of Food Processing and Technology, 10 (7), 1-7.

Kiferle, C., Lucchesini M., Mensuali-Sodi A., Maggini R., Raffaelli A. and Pardossi A. (2011). Rosmarinic acid content in basil plants grown in vitro and in hydroponics. Cent. Eur. J. Biol., 6: 946 - 957.

Lachowicz, K.J., Jones G.P., Briggs D.R., Bienvenu F.E., Wan J., Wilcock A. and Coventry M.J. (1998). The synergistic preservative effects of the essential oils of sweet basil (Ocimum basilicum L.) against acid-tolerant food microflora. Lett Appl Microbio., 26: 209 - 214.

Lahsasni, S., Kouhila M. and Mahrouz M. (2004). Adsorption-desorption isotherms and heat of sorption of prickly pear fruit (Opuntia ficus indica). Energy Conversion and Management, 45(2): 249 - 261.

Özcan, M. and Chalchat J.C. (2002). Essential oil composition of Ocimum basilicum $L$. and Ocimum minimum L. in Turkey. Czech J. Food Sci., 20: 223 - 228.

Özcan, M. and Chalchat J.C. (2002). Essential oil composition of Ocimum basilicum L. and Ocinum minimum L. in Turkey. Czechoslovak Journal of Food Science, 20(6): 223-228.

Özcan, M., Arslan D. and Ünver A. (2005). Effect of drying methods on the mineral content of basil (Ocimum basilicum L.). J Food Process Eng. 69: $375-379$.

Silakul, T. and Jindal V.K. (2002). Equilibrium moisture content isotherms of mungbean. International Journal of Food Properties, 5(1): 25-35.

Soysal, Y. and Oztekin S. (1999). Equilibrium moisture content equations for some medicinal and aromatic plants. Journal of Agricultural Engineering Research, 74(3): 317-324. 


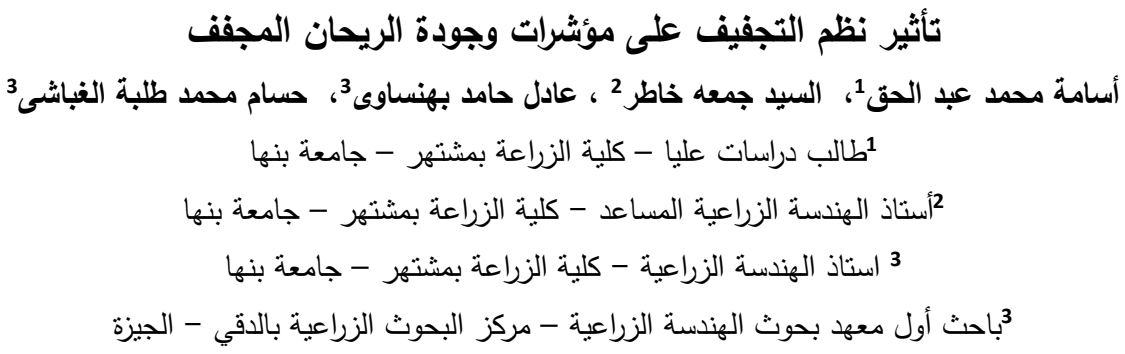

من أكثر المشكلات التى تواجه انتاج النباتات الطبية والعطرية هى قابليتها العالية للتحلل والتعفن مما يجعلها غير صالحة للاستهلاك أو على الأقل تصبح فى صورة غير جاذبة للمستهلك، ويهدف هذا البحث الى دراسة إمكانية تجفيف الريحان تحت نظم تجفيف مختلفة. ونم إجراء هذه التجربة فى قسم هندسة النظم الزراعية والحيوية - كلية الزراعة بمشتهر - جامعة بنها - محافظة القليوبية. وتم تجفيف الريحان تحت خمس نظم الته وهم: التجفيف الثمسى الطبيعى والتجفيف فى الظل والتجفيف فى الغرفة والتجفيف الثمسى الغير مباشر والتجفيف فى الفرن. وتم تقدير كلا من

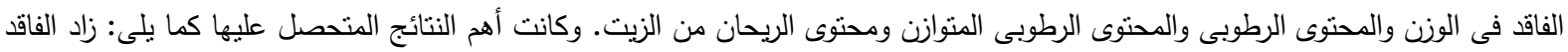

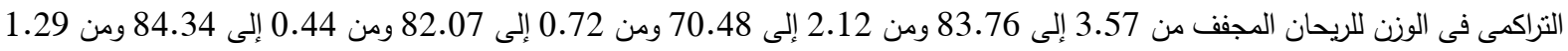
إلى 90.90\% لكل من نظام التجفيف الثمسى الطبيعى والتجفيف فى الظل والتجفيف فى الغرفة والتجفيف الثمسى الغير مباشر والتجفيف فى الفرن

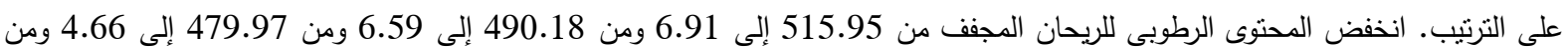
538.02 إلى 0.93 ومن 565.40 إلى 5.40 \% على أساس الوزن الجاف لكل من نظام التجفيف الثمسى الطبيعى والتجفيف فى الظل والتجفيف

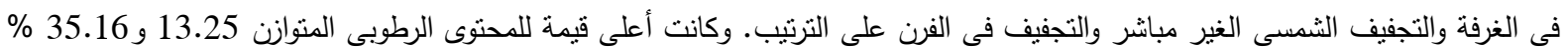

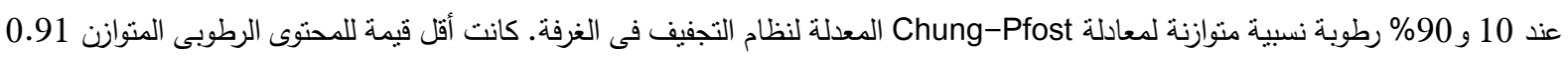
و 16.58\% عند 10 و 90\% رطوبة نسبية منوازنة لمعادلة Oswin المعدلة لنظام التجفيف فى الفرن. كان محتوى الريحان من الزيت 2.3 و 2.5 و 2.9 و 2.7 و 2.0 \% لكل من نظام التجفيف الثمسى الطبيعى والتجفيف فى الظل والتجفيف فى الغرفة والتجفيف الثمسى الغير مباثر والتجفيف فى الفرن على التزتيب. 